\title{
Strategies for reduction in the prevalence of NIDDM; the case for a population-based approach to the development of policies to deal with environmental factors in its aetiology
}

\author{
B.J. Boucher \\ Cellular Mechanisms Research Group, Academic Medical Unit, London Hospital Medical College, London, UK
}

The debate on Nature vs Nurture in the causation of human diabetes mellitus has been greatly enlivened by the work of Hales and Barker and others [1-4] on the relationship of adult non-insulin-dependent diabetes (NIDDM) and associated disorders to low birth weight. Though low birth weight could reflect rather than cause syndrome $X$, the prevalence of NIDDM and its associated hypertension and lipid disorders, indeed most of the features of syndrome X, may be increased in adults who had a low weight and a small head circumference at birth as a result of fetal deprivation rather than as a result of genetic factors alone. This concept is attractive since it supports the idea that there may be easier ways to reduce the growing burden of diabetes than identification of the genetically 'high-risk' individual.

Epidemiological evidence suggests that environmental factors are active in the aetiology of insulindependent diabetes (IDDM) [5]. Critical evaluation of the evidence suggests that $60-90 \%$ of diabetes prevalence is environmentally determined within affected populations, an appraisal that has not been challenged [6]. Many studies have been made on the environmental factors associated with an increased prevalence of NIDDM and one study in twins has suggested an increased role for environmental agents when compared to IDDM [7]. The possible significance of such findings continues to be discussed [8]. The criteria used in these studies are those accepted by the World Health Organisation to evaluate environmental contributions to cancer [9]. Their use in the examination of the evidence for envi-

Corresponding author: Dr. B. J.Boucher, The Medical Unit, The Royal London Hospital and London Hospital Medical College, London E11 1BB, UK

Abbreviations: NIDDM, Non-insulin-dependent diabetes mellitus; IDDM, insulin-dependent diabetes mellitus. ronmental 'triggering' of NIDDM is of interest since they should introduce order into the disparate information that is now available and facilitate analysis of its significance. Determination of the relative contributions made by the various factors under debate could provide direction for effective health education and health promotion. This could be useful in communities with an increasing prevalence of diabetes in the same way as exercise, dietary adjustments and avoidance of smoking are in the reduction of heart disease [10] and lung cancer [11]. Significant burdens on health care services as well as much misery for individuals might thereby be reduced. We show here examples of the available evidence for environmental causation, or 'triggering' of NIDDM:

It should be possible to produce NIDDM in laboratory animals by exposure to certain environmental agents. Food itself in excess is an inducer of NIDDM in some strains of mice [12], and variations in diet induce different incidences of NIDDM in susceptible rodents [13]. Vitamin D deficiency impairs insulin release followed, if prolonged, by impairment of insulin secretion and reduction of glucose tolerance which progresses to irreversible diabetes [14-16]. Protein deficiency during pregnancy in the rat causes failure to grow, reduced glucose utilisation and increased insulin resistance in the conceptus $[17,18]$. The influence of parental diabetes, especially in the mother, in producing subsequent diabetes in offspring can be considered to reflect genetic transmission [19], but, whilst maternal hyperglycaemia protects offspring against IDDM [20], it appears to be a potent agent in the induction of NIDDM [21]. Many naturally occurring nitrosated compounds damage islets with subsequent reduction in insulin production, abnormally large regenerative islets, and diabetes without insulin dependence [22-24]. Neonatal exposure to streptozotocin induces a non-insulin-dependent type 
of diabetes in the adult rodent [24]. Similar changes have been found in $8.3 \%$ of CD-1 mice given $20 \%$ betel-nut (Areca-nut) feed for 5 days, and in $25.6 \%$ of non-betel-fed F1 and in $12.9 \%$ of F2, $3.0 \%$ of F3 and $22 \%$ of $\mathrm{F} 4$ offspring [25, J.M. Stowers, personal communication]. The diabetes produced is non-insulin-dependent and though the mechanisms involved are unknown, maternal hyperglycaemia is not a factor. It may be due to specific Arecal nitrosamines [25] in much the same way as is seen in F1 offspring after comparable feeding of adult CD1 mice with Icelandic smoked cured mutton or with the specific nitrosamines it contains [26, 27].

There should be considerable geographical differences in the incidence of NIDDM. This is certainly true for the prevalence of NIDDM with, for example, $3 \%$ of Caucasians and $10-15 \%$ of various Asian groups having the condition in the United Kingdom, whilst forty percent of Nauruans and $66 \%$ of older Pima Indians have NIDDM [28-31].

In some populations there should be rapid temporal changes in incidence in less than a generation which could not be accounted for by genetic change. There are examples from various parts of the world where observations on the prevalence of NIDDM show that this does occur, and is not due to differences in ascertainment. For example, NIDDM increased in parts of Western Samoa from 0.1 to $5.3 \%$ between 1978 and 1991 and from 8.2 to $13.5 \%$ in women in urban areas [32]. In Nauru the prevalence rose by $40 \%$ between 1965 and 1975; whilst its incidence remained constant the prevalence of impaired glucose tolerance fell from $21.1 \%$ in $1975 / 1976$ to $8.7 \%$ in 1987 [33]. Similar trends have been seen in Hispanic Americans [34, 35].

The risk to immigrants of developing NIDDM should rapidly rise to that of the host country. NIDDM has been found to increase in prevalence in Asians who migrate to more affluent communities, often in the western world, and also in members of rural communities who move to cities and assume an urban life style [36, 37]. Whilst it may be underestimated in some studies, prevalence may be rising in rural areas [38].

There should be strong epidemiological evidence that certain environmental agents cause NIDDM in man. Affluence, obesity and lack of exercise are associated with increased prevalence of human diabetes [39], and the value of increased exercise and weight control in reducing the risk of diabetes has already been demonstrated [40]. The rat poison Vacor leads to diabetes in survivors of accidental poisoning in man, and whilst poisoning in the United States where packets contain $760 \mathrm{mg}$ of active agent pro- duced IDDM in survivors, in Korea only $20 \%$ of survivors developed IDDM, $80 \%$ developing the noninsulin-dependent type; the packets sold there containing only $360 \mathrm{mg}$ of active agent [41].

Malnutrition is associated with fibrocalculous pancreatic damage with diabetes in man [42]. The findings of Hales and Barker [1] that small babies in the United Kingdom have an increased risk of later developing NIDDM and associated markers of diabetes and vascular disease, have now been confirmed by similar findings in the United States [43]. If the suggestion that this reflects gestational nutrition rather than simply inherent genetic factors is substantiated, such data will need to be evaluated under this heading. Cigarette smoking has now been shown to be associated with increased prevalence of NIDDM in a study on American women [44]. Insulin resistance, which contributes to the development of NIDDM, has been suggested to be genetic in origin in some racial groups [45] but is acquired with obesity and reduction in physical activity and as a result of certain drugs and situations with increased lipolysis and circulating non-esterified fatty acids [46-48].

\section{Discussion}

Genetic factors are likely to contribute significantly to susceptibility to development of NIDDM in man $[49,50]$. However, it is also clear that there are environmental agents or situations which cause its appearance in susceptible individuals which provide a basis upon which policies for reduction of its prevalence could be developed. The fact that tuberculosis was generally thought to be hereditary until the work of Koch in 1882 [51], despite observations such as those made by Smollet [52] many years earlier on the value of reducing cross-contamination, should not be forgotten. Simple observations often point the way to preventing disease despite the lack of understanding of its pathogenesis, as in the use of inoculation with cowpox for the prevention of smallpox [53]. The diabetogenicity of many of the factors mentioned may itself depend on various genetic factors, as for example in the feeding of genetically susceptible mice [54] and in the diabetogenicity of low-dose administration of streptozotocin which is MHC-type dependent in mice [55]. The finding that various agents can induce significant levels of diabetes in subsequent generations [25-27], and that offspring of rats rendered diabetic with low-dose streptozotocin are insulin resistant and can develop diabetes [56, J.M.Stowers, personal communication], suggests that there may be complex interactions between the susceptibility genes and the environmental agents precipitating diabetes. Such interactions make work in this field more difficult than might at first be apparent. 
As Rose pointed out [57], when considering any given disease the answer to "Why did this particular individual in this population get this disease?" is not necessarily the same as the answer to "Why does this population have so much disease?". Whilst prevention of IDDM is developing along the 'high-risk' approach which seeks to identify and protect susceptible individuals, and a similar approach has been suggested for NIDDM [58], it may well be that the "population' approach which seeks to identify and control environmental causes of high incidence [59] may prove more effective for NIDDM. These approaches should not conflict, but the priority with a common disorder should be 'to discover and control the causes of incidence' [59]. The report on diabetes to the United States Congress in 1976 [60] described increases in prevalence in diabetes from which one could extrapolate a predicted prevalence of $100 \%$ by the year 2040 . The need for action to reduce overall incidence is clear. The possibility of effecting a reduction in NIDDM by improving nutrition or removal of dietary toxins appears to be realistic [61]. If evaluation of the available epidemiological data for NIDDM indicated an environmental contribution to prevalence approaching the $60-90 \%$ suggested for IDDM, then the considerable body of knowledge in this field [62] could be applied with vigour. Trials of simple measures known to reduce insulin resistance, to improve maternal nutrition, to protect islet beta cells from toxins such as nitroso-compounds (e.g., administration of nicotinamide) and the correction of relevant vitamin deficiencies could be carried out [63-65]. Health professionals, governments and individuals alike could then be advised on ways to reduce the burden of diabetes on communities, individuals and the state. Appreciation of the dangers of smoking and of the value of exercise for the heart is already altering corporate, public and individual life styles in many affluent communities. Guidelines could be developed [66] and contribute to the formulation of regulations affecting the food industry, in designing core curricula for physical and health education in schools and in town and country planning of recreational facilities. Those in a position to work together on quantitative evaluation of the relevant epidemiological evidence on the induction of NIDDM, as is in progress for environmental agents in the causation of human cancer [67-70], should be supported. The World Health Organization, the European Association for the Study of Diabetes, with Eurodiab, are ideally placed to organise, host and support such international initiatives.

\section{References}

1. Hales CN, Barker DJP, Clark PMS et al. (1991) Foetal and infant growth and impaired glucose tolerance at age 64 . BMJ 303: 1019-1022

2. Hales CN, Barker DJP (1992) Type 2 (non-insulin-dependent) diabetes mellitus: the thrifty phenotype hypothesis. Diabetologia 35: 595-601

3. Barker DJP, Hales CN, Fall CHD et al. (1993) Type 2 (noninsulin-dependent) diabetes mellitus, hypertension and hyperlipidaemia (syndrome $\mathrm{X}$ ): relation to reduced fetal growth. Diabetologia 36: 62-67

4. Barker DJP (ed) (1992) Fetal and infant origins of adult disease. (Medical Research Council Environmental Epidemiology Unit, University of Southampton). BMJ Publishing Group, London

5. Karvonen M, Tuomilehto J, Libman I et al. for the World Health Organization DIAMOND Project Group (1993) A review of the recent epidemiological data on the worldwide incidence of type 1 (insulin-dependent) diabetes mellitus. Diabetologia 36: 883-893

6. Diabetes Epidemiology Research International (1987) Preventing insulin dependent diabetes mellitus: the environmental challenge. BMJ 295: 479-481

7. Kaprio J, Tuomilehto J, Koskenvuo M et al. (1992) Concordance for type 1 (insulin-dependent) and type 2 (non-insulin-dependent) diabetes mellitus in a population-based cohort of twins in Finland. Diabetologia 35: 1060-1067

8. Zimmet PZ (1992) Kelly West lecture 1991. Challenges in diabetes epidemiology - from West to the rest. Diabetes Care $15: 232-252$

9. Higginson J (1969) Present leads in cancer epidemiology. In: Morgan JP (ed) Proc. 8th Canadian Cancer Conference, Pergammon Press, Toronto pp 40-45

10. Helmrich SP, Ragland DR, Lueng RW et al. (1991) Physical activity and reduced occurrence of non-insulin dependent diabetes mellitus. New Engl J Med 325: 147-152

11. Doll R, Peto R (1981) The causes of cancer: quantitative estimates of avoidable risks of cancer in the United States today. J Nat Cancer Inst 66: 1191-1308

12. Adler JH, Lazarovici G, Marton M et al. (1988) Patterns of hyperglycaemia, hyperinsulinaemia and pancreatic insufficiency in sand rats (Psammomys obesus). In: Shafrir E, Renold AE (eds) Lessons from animal diabetes 2: frontiers in diabetes research. John Libby, London pp 169-171.

13. Coleman DL, Kuzava JE, Leiter EH (1990) Effect of diet on incidence of diabetes in nonobese diabetic mice. Diabetes 39: $432-436$

14. Gedik O, Akalin S (1986) Effects of vitamin D deficiency and repletion on insulin and glucagon secretion in man. Diabetologia 29: 142-145

15. Beaulieu C, Kestekian R, Havrankova J et al. (1993) Calcium is essential in normalizing intolerance to glucose that accompanies vitamin $D$ depletion in vivo. Diabetes $42: 35$ 43

16. Boucher BJ, Mannan N, Noonan K et al. (1994) Reduction in insulin secretion with vitamin $\mathrm{D}$ deficiency in Asians living in East London and improvement after treatment with vitamin D. Diabet Med 11 [Suppl]: \$38-P96 (Abstract)

17. Desai M, Crowther NJ, Lucas A et al. (1994) Programming of hepatic metabolism by early protein restriction. Diabetologia 37 [Suppl 1]: A71 (Abstract)

18. Holness MJ, Sugden MC (1995) Fetal growth retardation and insulin resistance induced by a low-protein diet during pregnancy. Proc Nat Soc (in press) (Abstract) 
19. Thomas F, Balkau B, Vauzelle-Kervroedan F et al. (1994) Maternal effect and familial aggregation in NIDDM: the Codiab Study. Diabetes 43 (1): 63-67

20. Gaughier D, Bihoreau M-T, Ktorza A et al. (1990) Inheritance of diabetes mellitus in relation to gestational hyperglycaemia. Diabetes 37: 724-739

21. Okamoto $H$, Yamamoto $H$, Takasawa $S$ et al. (1988) In: Shafrir E, Renold AE (eds) Frontiers in diabetes research: lessons from animal diabetes. John Libby, London pp 149157

22. Voss C, Harman K, Hartmann H et al. (1988) Diabetogenic affects of N-Nitrosomethylurea. Exp Clin Endocrinology 92: 25-31

23. Golden P, Baird L, Malaisse WJ et al. (1976) Effect of 1methyl 1-nitrosourea and streptozotocin on glucose induced secretion by isolated islets of Langerhans. Diabetologia 12: 207-209

24. Bonner-Weir S, Leahy JL (1988) Induced rat models of non-insulin-dependent diabetes. In: Shafrir E, Renold AE (eds) Frontiers in diabetes research: lessons from animal diabetes. John Libby, London pp 295-300

25. Boucher BJ, Ewen SWB, Stowers JM (1994) Betel nut (Areca catechu) consumption and the induction of diabetes in adult $\mathrm{CD} 1$ mice and their F1 and F2 offspring. Diabetologia 37: 49-55

26. Helgason T, Ewen SWB, Ross I et al. (1982) Diabetes produced in mice by smoked/cured mutton. Lancet II: 10171022

27. Helgasen T, Ewen SWB, Jaffrey B et al. (1984) N-Nitrosamines in smoked meats and their relation to diabetes. IARCS Sci Pub 57: 911-920

28. Tandhanand S, Vannasaeng S (1988) Diabetes in Asia. Int Diab Fed 33: 10-13

29. Simmons D, Williams DR, Powell MJ (1992) Prevalence of diabetes in different regional and religious South Asian communities in Coventry. Diabet Med 9(5): 428-431

30. Alberti KGMM, Boucher BJ, Hitman GA et al. (1990) Diabetes mellitus. In: Cohen RD, Lewis B, Alberti KGMM, Denman AM (eds) The metabolic and molecular basis of acquired disease. Balliere Tindall, London pp 765-840

31. Zimmet P, Dowse G, Finch C et al. (1990) The epidemiology and natural history of NIDDM; lessons from the South Pacific. Diabetes Metab Rev 6: 91-124

32. Collins VR, Dowse GK, Toelupe PM et al. (1994) Increasing prevalence of NIDDM in the Pacific island population of Western Samoa over a 13-year period. Diabetes Care 17: 288-296

33. Dowse GK, Zimmet PZ, Finch CF et al. (1991) Decline in incidence of epidemic glucose intolerance in Nauruans: implications for the "thrifty genotype". American J Epidemiol 133: 1093-1104

34. King H, Rewers M (1991) Diabetes in adults is now a Third World problem. Bull World Health Organization 69: 643648

35. Bennet PH, Knowler WC (1979) Increasing prevalence of diabetes in the Pima (American) Indians over a ten year period. In: Waldhouse WK (ed) Diabetes 1979: proceedings of the 10th Congress of the International Diabetes Federation. Exerpta Medica, Amsterdam pp 507-511

36. Ramachandran A, Snehalatha C, Dharmaraj D et al. (1992) Prevalence of glucose intolerance in Asian Indians: urbanrural differences and significance of upper body adiposity. Diabetes Care 15: 1348-1355

37. Ramachandran A, Jali MV, Mohan V et al. (1988) High prevalence of diabetes in an urban population in South India. BMJ 297: 587-590
38. Ramaiya KL, Kodali VR, Alberti KGMM (1990) Epidemiology of diabetes in Asians of the Indian subcontinent. Diabetes Metab Rev 6: 125-146

39. Henry RR (1994) Prospects for primary prevention of type 2 diabetes. Diabetes Reviews Int 3: 2-5

40. Trovati M, Carta Q, Cavalot F et al. (1984) Influence of physical training on blood glucose control, glucose intolerance, insulin secretion and insulin action in non-insulin dependent diabetic patients. Diabetes Care 7: 416-420

41. Karam JH, Lewitt PA, Young CW et al. (1980) Insulinopenic diabetes after rodenticide (Vacor) ingestion. Diabetes 29: 971-1304

42. WHO Study Group Report on Diabetes Mellitus (1985) Technical Report Series 727. World Health Organization, Geneva

43. Valdez R, Athens MA, Thompson GH et al. (1994) Birthweight and adult health outcomes in a biethnic population in the USA. Diabetologia 37: 624-631

44. Rimm EB, Manson JE, Stampfer MJ et al. (1993) Cigarette smoking and the risk of diabetes in women. Am J Publ Health 83: 211-214

45. Haffner SM, Fong D, Hazuda HP et al. (1988) Hyperinsulinaemia, upper body adiposity and cardiovascular risk factors in non-diabetics. Metabolism 37: 338-345

46. Williams B (1994) Insulin resistance: the shape of things to come. Lancet 344: 521-534

47. Bevilaqua S, Bonadonna R, Buzzigoli G et al. (1987) Acute elevation of free fatty acid levels leads to hepatic insulin resistance in obese subjects. Metabolism 36: 502-506

48. Himsworth HP (1936) Diabetes mellitus: its differentiation into insulin-sensitive and insulin-insensitive types. Lancet I: $127-130$

49. McCarthy M, Hitman GA (1993) The genetic aspects of non-insulin-dependent diabetes. In: Leslie RDG (ed) Causes of diabetes; genetic and environmental aspects. John Wiley, Chichester pp 157-187

50. Kahn CR (1994) Insulin action, diabetogenes, and the cause of type 2 diabetes. Diabetes 43: 1066-1084

51. Koch R (1882) Die aetiologie de tuberculose. Berl Klin Wchnschr 9: 221

52. Smollet T (1771) The Expedition of Humphrey Clinker. Penguin Classics (1967) London p 77

53. Jenner E (1798) Enquiry into the causes and effects of the variolae vaccinae. Royal Society, London

54. Jeanrenaud B (1988) From CNS pathology to insulin resistance in the genetically obese Zucker (fa/fa) rat. In: Shafrir E, Renold AE (eds) Lessons from animal diabetes 2: frontiers in diabetes research. John Libby, London 342-348

55. Tanaka SI, Nakajima AS, Inoue S et al. (1990) Genetic control by Ia subregions on $\mathrm{H}-2$ complex of incidence of streptozotocin induced autoimmune diabetes in mice. Diabetes 39: 1298-1304

56. Holemans K, Aerts L, van Assche FA (1991) Evidence for an insulin resistance in the adult offspring of pregnant STZ-diabetic rats. Diabetologia 34 (2): $81-85$

57. Rose G (1985) Sick individuals and sick populations. Int $\mathbf{J}$ Epidemiol 14: 32-38

58. Henry RR (1994) Prospects for primary prevention of type 2 diabetes mellitus. Diabetes Rev Int 3(3): 2-5

59. Khaw K-T (1994) Genetics and the environment: Geoffrey Rose revisited. Lancet 343: 838-839

60. Report of the National Commission on Diabetes to the Congress of the United States (1976) Vol 1. The longrange plan to combat diabetes. DHEW Pub. No. (NIH) 76-1018: 1

61. Pozza G, Garancini P, Gallus G (1994) Prevalence and incidence of NIDDM. In: Williams R, Papoz L, Fuller J (eds) 
Diabetes in Europe: a monograph on diabetes epidemiology in Europe. Produced as part of the Eurodiab' Concerted Action Programme of the European Community. John Libby, London pp 21-39

62. Hales CN (1994) The pathogenesis of NIDDM. Diabetologia 37 [Suppl 2]: S162-S168

63. Leslie RDG (ed) (1993) Causes of diabetes; genetic and environmental factors. John Wiley, Chichester

64. Akpan JO (1988) The characterization of the protection by nicotinamide against the action of diabetogenic nitrosoureas. Diabet Metab 14: 693-699

65. Boucher BJ, Mannan N, Noonan K, Hales CN, Evans SJW (1995) Glucose intolerance and impairment of insulin secretion in relation to vitamin D deficiency in East London Asians. Diabetologia (in press)
66. Tuomilehto J, Knowler WC, Zimmet P et al. (1992) Primary prevention of non-insulin-dependent diabetes mellitus. Diabetes Metab Rev 8: 339-353

67. Marti B (1991) Health effect of recreational running in women. Some epidemiological and preventative aspects. Sports Med 11: 20-51

68. IARC (WHO) (1984) N-Nitroso compounds, occurrence, biological effects and relevance to human cancer. IARC Sci Publ 57, IARC Sci Publ Int Agency for Research on Cancer, Lyon

69. IARC (1990) Evaluating effectiveness of primary prevention of cancer. IARC Sci Publ 103 Int Agency for Research on Cancer, Lyon pp 1-201

70. IARC (1985) Carcinogenic risk to humans; tobacco habits other than smoking; betel quid and areca-nut chewing and some related nitrosamines. IARC Sci Publ 37, Int Agency for Research on Cancer, Lyon 